(C) 2014

Харченко Ю. В., кандидат сільськогосподарських наук, Харченко Л. Я., науковий співробітник

Устимівська дослідна станція рослинництва

Тимчук С. М., Поздняков В. В., кандидати біологічних наук, Супрун О. Г., науковий співробітник

Інститут рослинництва ім. В. Я. Юр'єва НААН

\title{
ВИВЧЕННЯ ВИХІДНОГО МАТЕРІАЛУ ДЛЯ СЕЛЕКЦЇ̈ КУКУРУДЗИ ХАРЧОВОГО Й ТЕХНІЧНОГО ПРИЗНАЧЕННЯ НА УСТИМІВСЬКІЙ ДОСЛІДНІЙ СТАНЦІЇ РОСЛИННИЦТВА
}

\section{Рецензент - кандидат сільськогосподарських наук О. В. Тригуб}

\begin{abstract}
Встановлено широку мінливість ліній - носїв різних ендоспермових мутацій - за зерновою продуктивністю, вмістом і фракційним складом крохмалю, а також вмістом та жирнокислотним складом олії. Показано, щзо поліпшення кукурудзи за ичми показниками потребує використання широкого генетичного різноманіття культури і створення якісного вихідного матеріалу. Визначено ефекти комбінаційної здатноcті ліній - носїв мутацій wx, su, ae, $s u_{1} m a s h_{2}-з a$ цими ознаками. Виділено перспективний вихідний матеріал для селекиії кукурудзи харчового й технічного призначення.
\end{abstract}

Ключові слова: кукурудза, ендоспермові мутанти, зернова продуктивність, якість продукиії, мінливість.

Постановка проблеми. У багатьох країнах світу кукурудза займає чільне місце серед сільськогосподарських культур. Різні частини цієї рослини використовуються як у сільському господарстві (перш за все в тваринництві), так і промисловості (медичній, переробній, харчовій).

У наш час кукурудза має понад 3,5 тисячі різних способів використання. Первинними продуктами промислової переробки кукурудзи є сироп, крохмаль і декстроза. Кожний із цих продуктів використовується як для технічних потреб, так і для харчової та фармацевтичної промисловості. Кукурудзяний крохмаль незамінний у виробництві наждачного паперу, електробатарей, вати, шкільної крейди, піротехнічних речовин, порошкових інсектицидів, мастильних речовин, автомобільних фарб. Він входить до складу аспірину, дитячого харчування, харчового розрихлювача, жуйок, а також напівфабрикатів для виготовлення пудингів i тістечок. Виробництво поштових конвертів, свічок, взуттєвих кремів, косметичних засобів, шпагату, соломинок для коктейлю і речовин, які містяться в складі сірникових головок і пачок, теж не обходиться без кукурудзяного крохмалю. Як відомо, близько
25 \% зародкової маси в кукурудзяному зерні займає цінна рослинна олія, що використовується в харчовій промисловості у виготовленні маргарину, майонезу, салатних соусів, картопляних чіпсів, приправ i супів. Фармацевти розчиняють у кукурудзяній олії вітаміни й активні інгредієнти лікарських препаратів. Окрім харчової промисловості й фармацевтики, кукурудзяну олію застосовують у виготовленні мила, лінолеуму, лакофарбових виробів, інсектицидів і речовин для боротьби 3 іржею. Отже, створення нового вихідного матеріалу для селекції сучасних високопродуктивних сортів та гібридів кукурудзи 3 певними технологічними й харчовими властивостями є актуальним та інноваційно затребуваним.

Аналіз останніх досліджень і публікацій, у яких започатковано розв'язання проблеми. Кукурудза є однією з найбільш розповсюджених зернових культур світу. Вона відзначається високою продуктивністю, добре пристосована до вирощування в широкому діапазоні агрокліматичних умов, забезпечує можливість отримання низки цінних продуктів промислової переробки і серед культурних рослин представлена найбільшим генетичним різноманіттям, яке може бути результативно використане в селекції $[10,11]$.

Наразі у кукурудзи ідентифіковано близько 20 моногенних ендоспермових мутацій із корисним ефектом за основними ознаками якості продукції $[8,9]$. Водночас встановлено, що ці ознаки можуть контролюватися також полігенними комплексами, здатними викликати самостійну дисперсію за показниками якості продукції й модифікувати ефекти моногенних мутацій [7, 16]. Використання ефекту саме цих генетичних систем вважається найвиправданішим шляхом поліпшення якості продукції у кукурудзи та створення гібридів харчового й технічного призначення [12].

Відомо, що кукурудза вирізняється можливістю багатоцільового використання товарної продукції, й одним 3 його основних напрямів $є$ ви- 


\section{СІЛЬСЬКЕ ГОСПОДАРСТВО. РОСЛИННИЦТВО}

робництво широкого спектру харчових і технічних продуктів [13]. Досвід промислового використання кукурудзи в зарубіжних країнах свідчить, що для цієї мети найбільш придатні гібриди 3 високою якістю зерна, сукупність показників якої відповідає специфічним вимогам промислової переробки [14]. В Україні створення гібридів такого типу практично не проводиться, що суттєво знижує результативність вітчизняного рослинництва, а також тих галузей промисловості, в яких використовується кукурудза.

Генетично поліпшуючи якість зерна кукурудзи слід враховувати, що іiі основні критерії у гібридів різних напрямів використання відмінні. Зокрема, у гібридів харчового й технічного призначення ними вважаються вміст і фракційний склад вуглеводів [18], а також вміст і жирнокислотний склад олії [15].

Однак поліпшення кукурудзи за цими ознаками потребує використання генетичного різноманіття культури і створення надійного вихідного матеріалу для селекції. Протягом останніх 15-и років було отримано перші вітчизняні лінії - ноciї різних ендоспермових мутацій, - i тому виникла необхідність визначення їх практичної цінності в різних екологічних зонах, у тому числі й південному Лісостепу України. Вищенаведене i створило передумови для виконання наших досліджень.

Мета і завдання досліджень. Метою досліджень було комплексне вивчення в умовах південного Лісостепу України ліній - носіїв ендоспермових мутацій wx, su 2 , ae, $\mathrm{su}_{1}$ та $\mathrm{sh}_{2}-$ як вихідного матеріалу для створення гібридів харчового й технічного призначення. Конкретні завдання досліджень передбачали:

- аналіз ефекту різних ендоспермових мутацій за продуктивністю, а також вмістом і складом крохмалю та олії;

- визначення мінливості продуктивності, а також вмісту й складу крохмалю та олії у різних ліній на основі однієї мутації;

- встановлення ефектів комбінаційної здатності ліній - носіїв різних ендоспермових мутацій за продуктивністю й основними показниками якості продукції;

- виділення найбільш перспективного вихідного матеріалу для селекції гібридів кукурудзи харчового і технічного призначення.

Матеріал і методика досліджень. Матеріалом для досліджень у 2008-2013 рр. слугувала серія неспоріднених за походженням інбредних ліній - носіїв ендоспермових мутацій $\mathrm{wx}, \mathrm{su}_{2}, \mathrm{ae}$, $\mathrm{su}_{1}$ та $\mathrm{sh}_{2}$, - а також серія простих гібридів, які було отримано внаслідок діалельних схрещувань цих ліній за другим методом Гріффінга.

Польові досліди проводили згідно із загальноприйнятою методикою польового експерименту [1] 3 урахуванням зональних особливостей вирощування кукурудзи, а обліки продуктивності ліній та гібридів - відповідно до методики Національного центру генетичних ресурсів рослин України [4].

Вміст крохмалю в зерні аналізували поляриметричним методом Еверса, фракційний склад крохмалю - колориметричним методом Джуліано, вміст олії в зерні - гравіметричним методом Рушковського [5], а жирнокислотний склад олії - газо-хроматографічним методом Пейскера [6]. Отримані результати проходили статистичну обробку методами дисперсійного та діалельного аналізу з використанням алгоритму Хеймана $[2,3]$.

Результати дослідження. До останнього часу гібридний склад кукурудзи в Україні був майже повністю представлений гібридами звичайного типу, через що в колекціях вихідного матеріалу цей тип кукурудзи також займає чільне місце.

Роботу з вихідним матеріалом для селекції гібридів кукурудзи харчового й технічного призначення на Устимівській дослідній станції рослинництва було розпочато в 2008 році.

За цей час проведено комплексні польові та лабораторні випробування і розмноження ліній 3 генетично поліпшеною якістю продукції, здійснено їх екологічне випробування, встановлено ефекти взаємодій генів: генотип за зерновою продуктивністю, а також вмістом та якістю крохмалю й олії, визначено ефекти комбінаційної здатності ліній - носіїв ендоспермових мутацій за цими ознаками і виділено найбільш перспективний вихідний матеріал для селекції кукурудзи харчового й технічного призначення.

1. Зернова продуктивність ліній кукурудзи носіїв різних ендоспермових мутацій в умовах Устимівської дослідної станції рослинництва в 2009-2010 рр., г зерна з рослини

\begin{tabular}{|c|c|c|}
\hline Типи ліній & $\begin{array}{c}\text { Розмах } \\
\text { (мін.- макс.) }\end{array}$ & $\begin{array}{c}\text { Середнє } \\
\left(\mathrm{x} \pm \mathrm{s}_{\mathrm{x}}\right)\end{array}$ \\
\hline Звичайні & $64,0-85,7$ & $74,0 \pm 3,3$ \\
\hline Мутанти $w x$ & $56,1-85,7$ & $67,8 \pm 5,0$ \\
\hline Мутанти $s u_{2}$ & $50,1-74,6$ & $62,3 \pm 3,6$ \\
\hline Мутанти $a e$ & $58,0-75,6$ & $66,9 \pm 2,3$ \\
\hline Мутанти $s u_{1}$ & $55,0-74,7$ & $64,5 \pm 3,2$ \\
\hline Мутанти $s h_{2}$ & $42,5-51,4$ & $45,7 \pm 1,3$ \\
\hline
\end{tabular}

Результати вивчення ліній-носіїв різних ендоспермових мутацій в умовах Устимівської дослідної станції показали значні відмінності між ними за зерновою продуктивністю (табл. 1). 


\section{СІЛЬСЬКЕ ГОСПОДАРСТВО. РОСЛИННИЦТВО}

Усі ендоспермові мутанти поступалися за середнім рівнем зернової продуктивності звичайній кукурудзі, однак найменшу депресію iï продуктивності викликала мутація $w x$, а найбільшу - мутація $s h_{2}$. Такі ж закономірності ефекту ендоспермових мутацій зареєстровано і за вмістом крохмалю в зерні (табл. 2).

Усі ендоспермові мутанти вирізнялися зниженим вмістом крохмалю порівняно зі звичайною кукурудзою, але серед них найвищий середній вміст крохмалю виявлено у носіїв мутації $w x$, а найнижчий у носіїв мутації $s u_{l}$.

За середнім вмістом амілози в крохмалі ендоспермові мутанти кукурудзи чітко розподілялися на дві уособлені групи. До першої з них належали носії мутації $w x$, крохмаль яких, на відміну від звичайної кукурудзи, майже повністю складався з амілопектину.

Представники другої групи мутацій $\left(s u_{2}, a e\right.$, $s u_{1}$ та $s h_{2}$ ) порівняно зі звичайною кукурудзою вирізнялися більш високим вмістом амілози в крохмалі, й цей ефект був особливо виражений у мутантів $a e$ та $s u_{2}$.

Усі ендоспермові мутанти перевищували зви- чайну кукурудзу за середнім вмістом олії в зерні; iii найвищий рівень виявлено у ліній на основі мутацій $s u_{1}$ та $s h_{2}$ (табл. 3).

Жирнокислотний склад олії було представлено 8-ма компонентами, однак сумарна частка п'яти 3 них не перевищувала $95 \%$ і кількісно переважаючими компонентами фракції гліцеридів були гліцериди пальмітинової, олеїнової та лінолевої кислот. Найбільшої практичної уваги заслуговує поліпшення кукурудзи за вмістом олеату, поскільки олії з його високим вмістом вирізняються значною стійкістю до перекисного окислювання [17].

Носії мутації $w x$ за середнім вмістом гліцеридів олеїнової кислоти практично не відрізнялися від звичайної кукурудзи, тоді як іншим мутантам (особливо $s u_{1}$ та $s h_{2}$ ) був властивий підвищений вміст олеату.

Результати проведених досліджень свідчать, що зернова продуктивність та основні ознаки якості продукції у різних ліній - носіїв однієї мутації мають кількісну природу й вирізняються досить широкою мінливістю (табл. 1-3).

\section{2. Вміст крохмалю та амілози в крохмалі зерна ліній кукурудзи - носіїв різних ендоспермових}

мутацій - в умовах Устимівської дослідної станцї̈ рослинництва в 2009-2010 рр.

\begin{tabular}{|c|c|c|c|c|}
\hline \multirow{2}{*}{ Типи ліній } & \multicolumn{2}{|c|}{$\begin{array}{c}\text { Вміст крохмалю в зерні, } \\
\text { \% абсолютно сухої речовини }\end{array}$} & \multicolumn{2}{|c|}{ Вміст амілози в крохмалі, \% } \\
\cline { 2 - 5 } & $\begin{array}{c}\text { розмах } \\
\text { (мін.- макс.) }\end{array}$ & $\begin{array}{c}\text { середнє } \\
\left(\mathrm{x} \pm \mathrm{s}_{\mathrm{x}} \text { ) }\right.\end{array}$ & $\begin{array}{c}\text { розмах } \\
\text { (мін.- макс.) }\end{array}$ & $\begin{array}{c}\text { середнє } \\
\left(\mathrm{x} \pm \mathrm{s}_{\mathrm{x}} \text { ) }\right.\end{array}$ \\
\hline Звичайні & $63,8-66,4$ & $64,9 \pm 0,4$ & $26,1-27,2$ & $26,7 \pm 0,2$ \\
\hline Мутанти $w x$ & $63,4-65,3$ & $64,4 \pm 0,3$ & $0,7-0,8$ & $0,8 \pm 0,1$ \\
\hline Мутанти $s u_{2}$ & $56,6-58,5$ & $57,6 \pm 0,3$ & $40,6-42,1$ & $41,1 \pm 0,2$ \\
\hline Мутанти $a e$ & $54,5-56,6$ & $55,3 \pm 0,3$ & $59,4-63,2$ & $61,2 \pm 0,6$ \\
\hline Мутанти $s u_{1}$ & $36,9-39,3$ & $37,9 \pm 0,4$ & $31,7-33,4$ & $32,6 \pm 0,2$ \\
\hline Мутанти $s h_{2}$ & $39,2-40,9$ & $40,0 \pm 0,2$ & $29,6-31,5$ & $30,6 \pm 0,3$ \\
\hline
\end{tabular}

3. Вміст олії та гліцеридів пальмітинової кислоти в олії ліній кукурудзи - носіїв різних ендоспермових мутацій - в умовах Устимівської дослідної станції рослинництва в 2009-2010 pp.

\begin{tabular}{|c|c|c|c|c|}
\hline \multirow{2}{*}{ Типи ліній } & \multicolumn{2}{|c|}{$\begin{array}{c}\text { Вміст олії в зерні, } \\
\text { \% до абсолютно сухої речовини }\end{array}$} & $\begin{array}{c}\text { Вміст гліцеридів олеїнової кислоти } \\
\text { в олії, \% до суми гліцеридів }\end{array}$ \\
\cline { 2 - 5 } & $\begin{array}{c}\text { розмах } \\
\text { (мін.- макс.) }\end{array}$ & $\begin{array}{c}\text { середнє } \\
\left(\mathrm{x} \pm \mathrm{s}_{\mathrm{x}} \text { ) }\right.\end{array}$ & $\begin{array}{c}\text { розмах } \\
\text { (мін.- макс.) }\end{array}$ & $\begin{array}{c}\text { середнє } \\
\left(\mathrm{x} \pm \mathrm{s}_{\mathrm{x}}\right)\end{array}$ \\
\hline Звичайні & $4,4-5,1$ & $4,8 \pm 0,2$ & $23,4-28,1$ & $25,5 \pm 1,4$ \\
\hline Мутанти $w x$ & $4,6-6,2$ & $5,2 \pm 0,2$ & $22,1-32,4$ & $25,6 \pm 1,5$ \\
\hline Мутанти $s u_{2}$ & $4,9-5,7$ & $5,1 \pm 0,1$ & $24,9-35,2$ & $28,2 \pm 1,5$ \\
\hline Мутанти $a e$ & $4,9-5,7$ & $5,2 \pm 0,1$ & $23,7-39,2$ & $30,2 \pm 2,5$ \\
\hline Мутанти $s u_{1}$ & $7,7-8,7$ & $8,2 \pm 0,1$ & $31,8-40,3$ & $37,8 \pm 1,2$ \\
\hline Мутанти $s h_{2}$ & $11,9-14,3$ & $13,2 \pm 0,3$ & $36,0-46,0$ & $39,0 \pm 1,6$ \\
\hline
\end{tabular}




\section{СІЛЬСЬКЕ ГОСПОДАРСТВО. РОСЛИННИЦТВО}

Окрім того в дослідах було встановлено значні відмінності комбінаційної здатності різних ліній - носіїв однієї мутації - за дослідженими ознаками.

Найвищі ефекти загальної комбінаційної здатності (ЗКЗ) та варіанси специфічної комбінаційної здатності (СКЗ) за зерновою продуктивністю і вмістом крохмалю в зерні з-поміж ліній на основі мутації $w x$ проявила лінія ВК-64, а вмістом олії в зерні - ВК-19. Лінії ВК-19 було властиво також найбільший ефект ЗКЗ за вмістом олеату, а найбільш широку варіансу СКЗ за цією ознакою зареєстровано у лінії ВК-11. Відмінності комбінаційної здатності за вмістом амілози в крохмалі у ліній на основі мутації $w x$ не спостерігалися.

Серед носіїв мутації $s u_{2}$ найвищі ефекти ЗКЗ за продуктивністю і вмістом амілози в крохмалі проявила лінія АC-37, за вмістом крохмалю AC-13, а за вмістом олії та олеату в ній - АC-32. Найбільш значні варіанси СКЗ за зерновою продуктивністю проявила лінія АС-52, вмістом крохмалю, амілози в крохмалі та вмістом олії - АC37, а вмістом олеату - АC-32.

3-поміж носіїв мутації ае найбільш високі ефекти ЗКЗ за продуктивністю і вмістом крохмалю зареєстровано у лінії АЕ-392, вмістом амілози та олеату - AE-466, а олії - AE-460. Найширші варіанси СКЗ за продуктивністю і вмістом крохмалю проявила лінія АЕ-466, амілози - АЕ-464, олії - АЕ-392, олеату- АЕ-801.

Серед ліній на основі мутації $s u_{1}$ найбільш високі ефекти ЗКЗ за продуктивністю і вмістом крохмалю були властиві лінії МC-401, за вмістом амілози та олеату - лінії МС-73, а за вмістом олії - лінії МС-713. Найширші варіанси СКЗ за продуктивністю проявила лінія МС-270, за вмістом олії - MC-713, а за рештою ознак - MC-11.

\section{БІБЛІОГРАФІЯ}

1. Доспехов Б. А. Методика полевого опыта / Б. А. Доспехов. - М. : Агропромиздат, 1985. - 351 с.

2. Лакин Г. Ф. Биометрия / Г. Ф. Лакин. - М. : Высшая школа, 1973. - $343 \mathrm{c.}$

3. Литун П. П. Генетика количественных признаков: генетические скрещивания и генетический анализ / П. П. Литун, Н. В. Проскурнин. К. : УМВО, 1992. - 96 с.

4. Методичні рекомендації польового та лабораторного вивчення генетичних ресурсів кукурудзи / підгот. І. А. Гур'єва, В. К. Рябчун, П. П. Літун [та ін.]. - Харків, 2003. - 43 с.

5. Методы биохимического исследования растений / под ред. А. И. Ермакова. - Л. : Агропромиздат, 1987. - 430 с.
Серед ліній - носіїв мутації $s h_{2}$ - найбільш високі ефекти ЗКЗ за продуктивністю й вмістом амілози проявила лінія SS-390, вмістом крохмалю - SS-566, олії - SS-389, а олеату - SS-386. Найширші варіанси СКЗ за продуктивністю показала лінія SS-390, за вмістом крохмалю та амілози - SS-566, олеату - SS-387, а олії - SS-385.

Кращі з виділених у дослідах гібридів за участю проаналізованих ліній передано до Державного сортовипробування. Сорт цукрової кукурудзи Білявка з 2014 року включено до Державного реєстру сортів України. Успішно завершено Державне сортовипробування гібридів восковидної кукурудзи Біном і цукрової Соло. До Державного сортовипробування підготовлено нові гібриди високолізинової та високоамілозної кукурудзи.

Висновки: 1. Найменше зниження зернової продуктивності та вмісту крохмалю серед ендоспермових мутацій викликає мутація $w x$. Найнижчою зерновою продуктивністю вирізняються носії мутації $s h_{2}$, а найнижчим вмістом крохмалю - носії мутації $s u_{l}$. Мутація $w x$ викликає утворення крохмалю, який майже повністю складається 3 амілопектину, а мутації ae та $s u_{2}$ мають крохмалі з підвищеною часткою амілози. Найширший вміст олії та гліцеридів олеїнової кислоти властивий носіям мутації $s h_{2}$.

2. Встановлено широку мінливість неспоріднених за походженням ліній - носіїв різних ендоспермових мутацій - за зерновою продуктивністю, вмістом і фракційним складом крохмалю, а також вмістом олії та олеату. Визначено ефекти комбінаційної здатності ліній - носіїв різних мутацій - за цими ознаками. Виділено перспективний вихідний матеріал для селекції кукурудзи харчового й технічного призначення.

6. Прохорова М. И. Методы биохимических исследований / М. И. Прохорова. - Л. : Химия, 1982. - 202 c.

7. Alrefai R. Quantitative trait locus analysis of fatty acid concentrations in maize / R. Alferai, T. G. Berke, T. R. Rocheford // Genome. - 1995. V. 38. - P. 894-901.

8. Boyer C. D. Kernel mutants of corn / C. D. Boyer, L. C. Hannah // Specialty Corns; A. Hallauer Ed. - Boca Raton, Fl. - London New York - Washington, D.C. : CRC Press, 2001.P. 10-40.

9. Coe E. Maize gene list and working maps / E. Coe, M. Polacco // Maize Genet. Newslett. 1994. - V. 68. - P. 156-191. 
10. Corn and corn improvement. $-3^{\text {rd }}$ ed./ ley's industrial oil and fat products, $6^{\text {th }}$ ed.; G. F. Sprague, J. W. Dudley Eds. - Madison, WI : American Society of Agronomy, 1988. - 986 p.

11. Corn: origin, history, technology and production / C. W. Smith, J. Betran, E. C. A. Runge Eds. Hoboken, New Jersey : John Wiley \& Sons Inc., 2004. - 949 p.

12. Dumanovic J. Specificni tipovi kukuruza / J. Dumanovic, Z. Pajic. - Beograd-Zemun : Institut za kukuruz «Zemun Polje», 1998. - 207 p.

13. Inglett G. E. Corn : culture, processing, products / G. E. Inglett. - Westport, Conn. : AVI Publ. Comp., 1970. -369 p.

14. Jugenheimer R. W. Corn : improvement, seed production and uses / R. W. Jugenheimer. - New-York : John Wiley \& Sons Inc., 1976. - 670 p.

15. Moreau R. A. Corn oil / R. A. Moreau // BaiF. Shahidi Ed.-Hoboken, New Jersey : John Wiley \& Sons Inc. - 2005. - V. 2. - P. 149-172.

16. Quantitative trait loci affecting amylose, amylopectin and starch content in maize recombinant inbred lines / M. Sene, M. Causse, C. Damerval [et al.] // Plant Physiol. Biochem. - 2000. - V. 38. P. 459-472.

17. Robbelen G. Mutant breeding for quality improvement. A case study for oilseed crop / G. Robbelen // Mutation Breed. Rev. - 1990. - V. 6. - P. 1-44.

18. Starch chemistry and technology, $3^{\text {rd }}$ ed./ J. Be Miller, R.Whistler Eds. - Amsterdam - Boston - Heidelberg - London - New York - Oxford Paris - San-Diego - San Francisco - Singapore : Acad. Press, Elsevier Publ., 2009. - 900 p. 